\title{
THE CAPITAL STRUCTURE OF VENTURE CAPITAL FIRMS IN INDONESIA
}

\author{
Andi Buchari \\ PT. Bahana Artha Ventura, Graha CIMB Niaga 18th Floor, \\ Jl. Jenderal Sudirman Kav.58, SCBD, Jakarta 12190 - Indonesia \\ Noer Azam Achsani \\ Mangara Tambunan \\ Tubagus Nur Ahmad Maulana \\ Program Doktor Manajemen dan Bisnis, Institut Pertanian Bogor \\ Jl. Raya Pajajaran, Bogor 16151 - Indonesia
}

\begin{abstract}
Venture capital (VC) is an important fund source for small and medium enterprises (SMEs) and start up, particularly to deliver its main product of equity participation. Therefore, capital structure and factors that affect it are very crucial. This study aims to analyze the capital structure of VC firms in Indonesia using econometric model of panel data regression. This study utilizes secondary data of six years period (20092014) monthly financial statements of 27 samples out of 58 VC firms to form 1,944 observations. The study reveals that capital structure of $V C$ firms in Indonesia is dominated by debt/loan rather than capital with DER on average is $136.95 \%$. In addition, the research confirms that VC firms' capital structure is affected simultaneously by financial aspects which are asset size, profitability, liquidity, asset/investment quality, and earning asset structure. The attentions to financial aspects that affect the VC firms' capital structure as well as other initiatives related to capital increases are necessary so that the VC firms could carry out its role effectively.
\end{abstract}

Key words: capital structure, financial aspects, start up and SMEs, venture capital

\section{INTRODUCTION}

Start up business and SMEs is very crucial to the economy in many countries. Nevertheless, it is a common phenomenon that the sectors have many weaknesses, for instance capital supports and fund sources. According to Oakey (2007), venture capital (VC) is important to be an appropriate source

Korespondensi Penulis:

Andi Buchari: Telp. +62 21 79182688; Fax. +62 2179182686

E-mail: andibuchari@ymail.com 


\section{Jurnal Keuangan dan Perbankan | KEUANGAN}

Vol. 20, No.3, September 2016: 407-416

of funding for start up and SMEs. Moreover, Hasan, Mikail, \& Arifin (2011) also stated that VC firms have a significant role in supporting enrepreneurs so that government in many countries provided support to the VC industry such as capital injection, funding facility, and regulatory framework.

Venture capital (VC) is a fund provided by the investors to invest in certain business, normally a start up or SMEs as investee companies, which are perceived have a long-term growth and potential return (Dipo, 1993; Budisulistyawati, 2006; Muliya \& Imaniyati, 2008; Metrick \& Yasuda, 2012). Jalil (2005) and Hussain (2011) stated that VC invests in companies in the form of equity participation in various business phase from seed, start up or early stage of financing, and in the expansion phase along with the involvement in the management (please see Picture 1).

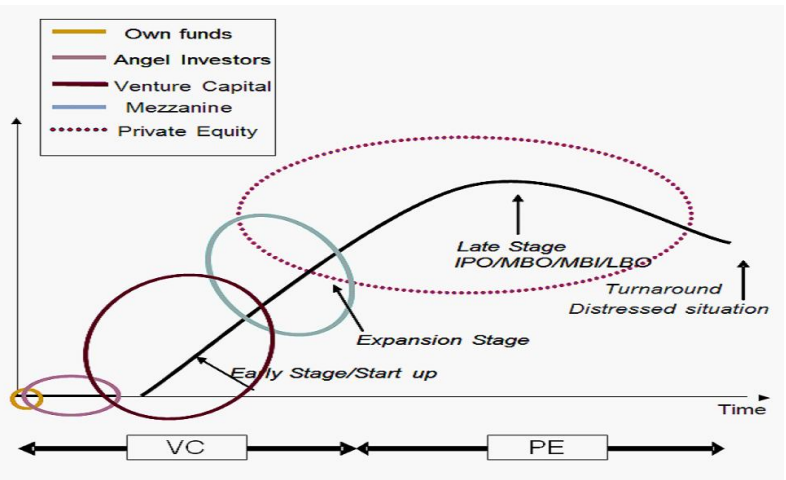

Picture 1. The Role of Venture Capital Firms (VC) in the Business Lifecycle (Source: Hussain, 2011)

According to Zott (1998), VC focuses on providing capital to the companies that have growth prospect, value creation, and feasible, although non-bankable. Therefore, VC has two important roles in the business activities, as pioneer of the entrepreneurship and source of capital. Hence, capital structure is very important for VC firms.

This study aims to analyze the capital structure of VC firms in Indonesia as well as to investi- gate determinant factors that simultaneously affect the VC firms' capital structure using econometric model of panel data regression.

Manurung (2012) defined capital structure as the structure of funding in the form of debt and equity capital in the company. Furthermore, there are some grand theories of capital structure: (1) Traditional Approach Theory, (2) Modigliani \& Miller (MM) Theory or Irrelevance Capital Structure Theory, (3) Pecking Order Theory (POT), (4) Trade-Off Theory (TOT), (5) Asymmetric Information Theory and Signaling Theory, (6) Agency Theory (Brigham \& Houston, 2006). Mamduh (2004) revealed some indicators affecting the debt policies in the firms: non-debt tax shield (NDTS), assets structure, profitability, business risk, size of firms, and internal condition.

Previous studies in capital structure such as Harris \& Raviv (1991); Saidi (2004); Lopez-Gracia \& Sogorb-Mira (2008); Joni \& Lina (2010); Panda (2012); Manurung (2012); Ayed \& Zouari (2014); Adiyana \& Ardiana (2014), found that there is a relationship between size and other financial determinants to the capital structure in certain industries in some countries. In addition, Mayangsari (2001) noted that some studies have been done in the determinants of capital structure of firms in different business sectors, among others in joint venture firms (Boateng, 2004); manufacturing sectors (Long \& Malitz, 1985; Titman \& Wessels, 1988), electric and utilities firms (Modigliani \& Miller, 1966), non profit hospital (Wedig, et al. 1988) and in agricultural firms (Jensen \& Langemeier, 1996). Some previous researches about capital structure in different sectors were done in Indonesia, such as in plantation companies (Munawar, et al. 2010), in public listed companies (Hardiyanto, et al. 2013), in corporate telecommunication operators (Sitorus, et al. 2014), and in state-owned banks (Raharjo, et al. 2014). However, study related to the VC firms' capital structure in Indonesia has not been found.

In Indonesia, the inception of VC firms was marked by the establishment of Bahana Artha 
Ventura as the first VC firm in 1993 (BPUI, 2014). Since then, the other VC firms were founded, including regional $\mathrm{VC}$ firms operated in some provinces, private VC firms, as well as joint venture VC firms.

However, the growth of VC firms in Indonesia is categorized low. Compared to other nonbank financial institutions, for instance Multifinance, total asset of VC firms is very small. According to Otoritas Jasa Keuangan/OJK (Financial Services Authority of Indonesia/FSA), the assets of Multifinance grew 4.33 times in the last 10 years with total assets of IDR 420.4 trillion in 2014. While, the assets of VC only grew 2.17 times in the last 10 years with total assets is only $2.14 \%$ of Multifinance (OJK, 2015c).

Moreover, the number of VC firms was decreased in recent years. Based on the OJK/FSA data, as of the second quarter 2015, the number of VC firms was 58, decreased from 89 (December 2012), 73 (December 2013), and 67 (December 2014) (OJK, 2013; OJK, 2014; OJK, 2015a; OJK, 2015b). The OJK/FSA data also shows that the composition of VC firms' portofolio has changed while the portion of equity participation (EP) was continuously decreased from $79 \%$ in 2012 has lowered to $68 \%$ in 2013 , and dropped to $14.5 \%$ in the second quarter 2015. This reflects that there are certain problems in the Indonesian VC firms/industry.

On the other hand, some foreign VC firms entered the market and disbursed huge amount of financing to the local start up, particularly ecommerce and digital business, for instance Northstar and Sequoia Capital in Gojek (on-line transportation by motorcycle); Cyberagent Venture, Softbank Internet and Media, and Sequoia Capital in tokopedia (e-commerce); Aufan, 500 startups, IREP, and Gree Ventures in Bukalapak (ecommerce) (Forbes Indonesia, 2015).

Hypothesis of the research is formulated to achieve the purpose of the study as well as based on theory or previous empirical research findings. To investigate the simultaneous influence of certain financial parameters of VC firms to the VC firms' capital structure, the alternative hypothesis $\left(\mathrm{H}_{\mathrm{A}}\right)$ for this study is "there is a simultaneous influence of asset size, profitability, liquidity, asset quality, and earning asset structure of $\mathrm{VC}$ firms to the VC firms' capital structure".

\section{METHODS}

This quantitative study is conducted in Indonesia, uses econometric approach of panel data

Table 1. Research Variables

\begin{tabular}{|c|c|c|c|}
\hline No. & Variable & Indicator (Proxy) & Measurement \\
\hline 1 & SIZE & Size of VC firms & Total Assets \\
\hline 2 & PROF & Profitability of VC firms & $\begin{array}{c}\text { Return on Equity (ROE) }= \\
\text { Earning After Tax/Total Equity }\end{array}$ \\
\hline 3 & LIQ & Liquidity of VC firms & $\begin{array}{c}\text { Current Ratio (CR) }= \\
\text { Current Asset/Current Liabilities }\end{array}$ \\
\hline 4 & ASQUL & Assets quality of VC firms & $\begin{array}{c}\text { Non-Performing Investment (NPI) }= \\
\text { Total NPI/Total Earning Assets }\end{array}$ \\
\hline 5 & EAR & Productive assets structure of \\
VC firms & $\begin{array}{c}\text { Earning Asset Ratio (EAR) }= \\
\text { Total Earning Asset (Investment and } \\
\text { Financing)/Total Asset }\end{array}$ \\
\hline 6 & DER & Capital structure of VC firms & $\begin{array}{c}\text { Debt to Equity Ratio (DER) }= \\
\text { Total Debt/Total Equity }\end{array}$ \\
\hline
\end{tabular}


analysis. The study utilizes secondary data of 27 samples out of $58 \mathrm{VC}$ firms' total population in Indonesia as of second quarter 2015. Data collected from monthly financial statements for 6 (six) consecutive years of 2009 up to 2014 to forms 1,944 observations. With this large amount of data, it can be assumed that the data are normally distributed.

The capital structure uses Debt to Equity Ratio (DER) as proxy of capital structure to study the simultaneous influence of several financial aspects to the VC firms' capital structure in Indonesia. In the regression analysis of data panel, DER is dependent variable (response variable), while total assets (TA), return on equity (ROE), current ratio (CR), non-performing investment (NPI), and earning assets ratio (EAR) are independent variables (explanatory variables). All research variables used in the study are shown in Table 1.

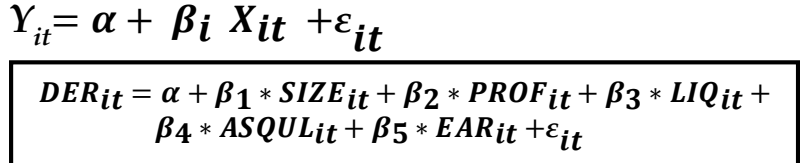

where:

$Y_{i t} \quad=$ Dependent variable for individual (i) and time $(\mathrm{t})$

DER $_{\text {it }} \quad=$ Debt to Equity Ratio for VC firms (i) in time $(t)$

$\mathrm{X}_{\mathrm{it}} \quad=$ Independent variables for individual (i) and time (t)

SIZE $_{\text {it }} \quad=$ Size of firm (Total Assets of VC firm)

$\mathrm{PROF}_{\text {it }} \quad=$ Profitability (reflected by Return on Equity/ROE)

LIQ $_{\text {it }} \quad=$ Liquidity (reflected by Current Ratio/ CR)

$\mathrm{ASQUL}_{\mathrm{it}}=$ Asset Quality (reflected by Non-Performing Investment/NPI)

Table 2. Descriptive Statistics

\begin{tabular}{|l|c|c|c|c|c|c|}
\hline & DER & SIZE & PROF & LIQ & ASQUL & EAR \\
\hline Mean & 136.9493 & 40.81782 & 2.334820 & 296.0059 & 17.14820 & 89.57495 \\
\hline Median & 111.6300 & 34.90172 & 0.860000 & 108.2900 & 11.95000 & 89.83500 \\
\hline Maximum & 48116.64 & 147.5312 & 2520.240 & 5260.070 & 98.65000 & 152.6000 \\
\hline Minimum & -20354.08 & 1.354034 & -304.9800 & -8082.900 & 0.020000 & 22.55000 \\
\hline Std. Dev. & 1646.809 & 31.00787 & 58.54897 & 553.6993 & 17.76883 & 12.81951 \\
\hline & & & & & & 1944 \\
\hline Observations & 1944 & 1944 & 1944 & 1944 & 1944 \\
\hline
\end{tabular}

Source: SPSS output

Table 3. Correlation Test

\begin{tabular}{ccccccc}
\hline & DER & EAR & NPI & ROE & TA & CR \\
\hline DER & 1.000000 & & & & & \\
EAR & 0.026521 & 1.000000 & & & & \\
NPI & 0.004187 & 0.269041 & 1.000000 & & & \\
ROE & -0.036765 & -0.013593 & 0.036755 & 1.000000 & & 1.000000 \\
TA & -0.001712 & -0.055266 & -0.373894 & -0.017282 & -0.171209 & 1.000000 \\
CR & 0.108776 & -0.124042 & 0.236029 & -0.001641 & & \\
\hline
\end{tabular}

Source: SPSS output 
EAR = Earning Asset Ratio (Investment and Financing to Assets Ratio/IFAR)

$\alpha=$ Constanta

$\beta_{1} \ldots \beta_{5}=$ Regression coefficient $\rightarrow$ will be estimated by Data Panel Regression

The criteria for acceptance or rejection of the hypothesis used in this study is to follow the general terms in which if the probability (a) $>0.05$ then $\mathrm{H}_{0}$ is not rejected $\left(\mathrm{H}_{\mathrm{A}}\right.$ is rejected $)$ so as if probability $(\mathrm{a})<0.05$ then $\mathrm{H}_{0}$ is rejected $\left(\mathrm{H}_{\mathrm{A}}\right.$ is not rejected).

\section{RESULTS \\ DISCUSSION}

Table 2 shows that VC firms' capital structure in Indonesia is $136.95 \%$, it means that the total loan used for the company's operations is greater than the total capital owned by the companies. This result supports the OJK/FSA data that in order to run their business, VC firms in Indonesia in general still rely on to the external funding sources, including bank loan and debt from several government bodies as well as non-government (OJK, 2015b). The provision of minimum capi-

Table 4. Hausmant Test

\begin{tabular}{lccc}
\hline \hline Test Summary & Chi-Sq. Statistic & Chi-Sq. d.f. & Prob. \\
\hline \hline Cross-section random & 33.198875 & 5 & 0.0000 \\
\hline \hline Source: Eviews output & & &
\end{tabular}

Table 5. Chow Test

\begin{tabular}{lccc}
\hline \hline Effects Test & Statistic & d.f. & Prob. \\
\hline \hline Cross-section F & 385.499680 & $(26,1912)$ & 0.0000 \\
\hline \hline
\end{tabular}

Source: Eviews output

Table 6. Fixed Effect Model (FEM)

\begin{tabular}{|c|c|c|c|c|}
\hline Variable & Coefficient & Std. Error & t-Statistic & Prob. \\
\hline EAR & 4.014482 & 0.253950 & 15.80816 & 0.0000 \\
\hline ASQUL & -3.725910 & 0.388001 & -9.602831 & 0.0000 \\
\hline SIZE & 1.660552 & 0.072679 & 22.84771 & 0.0000 \\
\hline PROF & -1.728233 & 0.857309 & -2.015880 & 0.0440 \\
\hline LIQ & 0.192314 & 0.013291 & 14.46974 & 0.0000 \\
\hline $\mathrm{C}$ & -279.4261 & 23.28724 & -11.99911 & 0.0000 \\
\hline R-squared & 0.891043 & Mean dependent var & & 1.221011 \\
\hline Adjusted R-squared & 0.889276 & S.D. dependent var & & 2.367863 \\
\hline S.E. of regression & 0.613304 & Sum squared resid & & 719.1836 \\
\hline F-statistic & 504.3915 & Durbin-Watson stat & & 0.852269 \\
\hline Prob(F-statistic) & 0.000000 & & & \\
\hline
\end{tabular}

Source: Eviews output 


\section{Jurnal Keuangan dan Perbankan | KEUANGAN}

Vol. 20, No.3, September 2016: 407-416

tal as the internal funding sources which is relatively small/low, most VC firms in Indonesia have a high level of dependency to the external funding sources, including from commercial banks and several institutions such as Lembaga Pembiayaan Ekspor Indonesia (LPEI)/Indonesia Eximbank, Lembaga Pengelola Dana Bergulir (LPDB) under the Ministry of Cooperative and SME, Partnerships and Community Development Program which is known as Program Kemitraan dan Bina Lingkungan (PKBL) of state-owned companies. Some VC firms with asset size more than Rp 1 trillion are known obtained funding support from overseas, such as from International Finance Corporation (IFC), an affiliate of the World Bank; Japan Export-Import Bank (JEXIM) Tokyo-Japan; Grameen Credit Agricole Foundation France; Triodos Investment Management Netherlands; etc. (OJK, 2015a).

In regards to the fund sources (liability side), the regulations noted that VC firm in Indonesia is prohibited to collect funds directly from the society unlike banking industry. It drives situation where debt/loan from banks and other institutions to become the main sources of fund for most VC firms. Those fund sources in general are short-term with a commercial interest rate. In terms of the distribution of funds (asset side), VC firm is not allowed to distribute funds in the form of nonproductive financing (consumer lending) unlike multi-finance company or banking industry. As a result, the limitation of business also contributes to the slow growth of assets for VC industry in Indonesia. Thus, the combination of internal factors such as the source of funds (liability side) and the distribution of funds (asset side) as well as the external factors such as regulatory issues (mandatory minimum capital requirement, etc.) are believed to become the cause total assets of VC industry in Indonesia is difficult to grow faster.

Prior to the regression of data panel, the bivariate analysis test namely Correlation Test (one of the classical assumption tests) reveals that there is no strong relationship between respective variables (financial parameters) used in this study, meaning that there is no multicolinearity problem. Please see Table 3 above. Bivariate correlation analysis tests the relationship between two variables that theoreticallycan be: perfectly not correlated $(r=0)$, perfectly correlated $(r=1)$, or in between of the two figures. The tests severally confirms that there is only weak correlated $(r<0.5)$ among variables of debt to equity ratio (DER), total asset (TA), return on equity (ROE), current ratio $(\mathrm{CR})$, non-performing investment (NPI), and earning asset ratio (EAR) which are used further in the panel data regression.

The analysis is then continued by series of tests to determine the best fit model, including Hausmant Test and Chow Test. The results can be seen in Table 4, Table 5, and Table 6 . The test series revealed that the best fit model is Fixed Effect Model (FEM).

Hausman test conducted to select the Fixed Effects Model (FEM) or Random Effects Model (REM), prob. values is $0.0000<0.05\left(\mathrm{H}_{\mathrm{A}}\right.$ is not rejected), so that FEM is chosen.

Chow test conducted to determine the Common Effect (OLS) or Fixed Effect Model (FEM). Prob. values is $0.0000<0.05\left(\mathrm{H}_{\mathrm{A}}\right.$ is not rejected), so that FEM is chosen. Therefore, statistically, it founds that the appropriate model is Fixed Effect Model (FEM) to run the panel data regression.

The study (see Table 6) reveals that the independent variables which are the company asset size, profitability, liquidity, asset quality, and earning asset structure are significant at the $95 \%$ confidence level ( $p$-value < 0.05) simultaneously affect the capital structure of the VC firms $\left(\mathrm{H}_{\mathrm{A}}\right.$ is not rejected).

The estimation of panel data regression using Fixed Effect Model (FEM) as mentioned on Table 6 results the following equation: DER $=$ 279.426 + 1.661 SIZE - 1.728 PROF + 0.192 LIQ 3.726 ASQUL + 4.014 EAR. 
The results as described on Table 6 also reveals that some classical assumptions have been fulfilled such as Durbin-Watson test (autocorrelation) and Goodness of Fit. The coefficient of determination (R-squared) 0.8910 means that the variables in this study explained $89.10 \%$ of the overall effect, while the remaining $10.90 \%$ by other variables are not examined.

The results supported the previous studies such as Harris \& Raviv (1991) that the determinants of capital structure are the level of profit, the size of the company and cash flow. Moreover, some previous studies find that capital structure is influenced by company size, profitability, business risk and asset structure of the company (Seppa, 2007; Vries, 2010; Al-Najjar \& Taylor, 2008; Su, 2010; Krishnan \& Moyer, 1996).

The above equation can be explained as follows:

a. Constanta. Constanta on the regression equation is -279.426 shows that with no influence of asset size, profitability, liquidity, asset quality and earning asset, debt to equity ratio is 279.426 .

b. Coefficient of asset size. Coefficient of asset size is 1.661 indicates that a one unit increases in total asset (TA) will increase debt to equity ratio of 1.661. The study shows significant result, where $(p=0.000)<(\alpha=0.050)$, it means that the increasing of asset size will significantly increase debt to equity ratio.

These results supported the studies conducted by Zonenschain (n.a); Singh \& Hamid (1992); Singh (1995), that generally in developing countries, companies prefer equity as source of funds rather than debt.

c. Coefficient of profitability. Coefficient of profitability is -1.728 indicates that a one unit increases in return on equity (ROE) will decrease debt to equity ratio of 1.728 . The study shows a significant result, where $(p=0.044)<(\alpha=$ $0.050)$, it means that the increasing of profit- ability will significantly decrease debt to equity ratio.

The results are consistent with the Pecking Order Theory (POT) as proposed by Myers (2001), that a company with high profitability tends to have a low debt due to a much of internal funds' sources. The results supported by previous studies by by Zonenschain (n.a) and Indahningrum \& Hand (2009).

d. Coefficient of liquidity. Coefficient of liquidity is 0.192 indicates that a one unit increases in current ratio $(\mathrm{CR})$ will increase debt to equity ratio of 0.192 . The study shows significant result, where $(p=0.000)<(\alpha=0.050)$, it means that the increasing of liquidity will significantly increase debt to equity ratio. So that the higher of DER derived from debt would improve the company's liquidity. This supported the implementation of asset and liability management (ALMA) that management may use the resources derived from debt (short-term) to meet the liquidity needs of the company, while for capital expenditure management may use equities (longer term) for a funding sources.

e. Coefficient of asset quality. Coefficient of asset quality is -3.726 indicates that a one unit increases in non-performing investment (NPI) will decrease debt to equity ratio of 3.726 . The study shows significant result, where $(\mathrm{p}=$ $0.000)<(\alpha=0.050)$, it means that the increasing of NPI will significantly decrease debt to equity ratio. The higher NPI could lowering the interest of the creditors to provide debt/ loan for the VC firms.

f. Coefficient of earning asset. Coefficient of earning asset is 4.014 indicates that a one unit increases in earning asset ratio (EAR) or investment and financing to assets ratio (IFAR) will increase debt to equity ratio of 4.014. The study shows significant result, where $(\mathrm{p}=$ $0,000)<(\alpha=0,050)$, it means that the increas- 


\section{Jurnal Keuangan dan Perbankan | KEUANGAN}

Vol. 20, No.3, September 2016: 407-416

ing of EAR or IFAR will significantly increase debt to equity ratio. The results are caused by the fact that the biggest portion of $\mathrm{VC}$ financing to investee companies is dominated by profit/revenue sharing scheme for about $70 \%$, followed by equity participation $19 \%$, and convertible bonds for about $11 \%$ (OJK 2015). Most of VC firms' portfolio is in short-term financing ( 3 years tenor) driven by sources of fund dominated by commercial debt/loans from banks. Therefore, it is difficult for VC firms to make a long-term financing such as equity participation.

\section{MANAGERIAL IMPLICATIONS}

Several key issues related to the VC firms' capital structure in Indonesia need to get attention from the stakeholders in respect to the results of the study. A stronger VC firms' capital structure with higher portion of equity is necessary, not only to support a faster growth of VC firms/industry in Indonesia but also to face competition with foreign VC firms supported by a strong capital which has been aggressively entering the Indonesian market.

In terms of non-organic growth of capital, it is suggested that the VC firms should increase their capital through the capital raising program, among others with the injection of capital by the existing shareholders or inviting new shareholders/investors or through mergers and acquisitions. Qualified VC firms could take a way for the initial public offering/IPO (go public). For the state-owned VC firms, besides the initiative of state capital participation ("Penyertaan Modal Negara" or PMN), the government could obtain the capital strengthening with the consolidation or merger of several stateowned VC firms.

A strong of capital would also lead VC firms in Indonesia back to its nature in which the portfolio of VC firms will be dominated by the scheme of equity participation. The scheme is considered as the value proposition that could differentiate the VC firms to the other financial institutions.

Considering that there is a simultaneous influence of various financial aspects including assets size, profitability, liquidity, asset quality, and productive assets structure on the VC firms' capital structure in Indonesia, it is necessary to undertake some efforts to increase the financial performance of VC firms. It may provide a good impact to the improvement of VC firms' capital structure as organic growth of capital.

\section{CONCLUSION}

The study finds that the average DER of VC firms in Indonesia is $136.95 \%$ (1.37 times) indicates that the capital structure of VC firms is dominated by debt including loan from banks. Hence, many VC firms have problems to provide equity participation as the core product of venture capital. This result is in line with the OJK/FSA statistical data stated that in recent years the composition of the portfolio of the VC industry in Indonesia has been dominated by revenue/profit sharing financing rather than equity investment.

In addition, the study also reveals that the VC firms' capital structure is affected simultanously by its asset size, profitability, liquidity, investment quality, and earning asset with 0.8910 coefficient of determination. This indicates that the variables studied could explain $89.10 \%$ of the overall effect, while the remaining $10.90 \%$ by other variables not examined. The result indicates that all independent variables are significantly at the $95 \%$ confidence level affect the VC firms' capital structure (dependent variables).

\section{SUGGESTION}

To enhance the role of VC firms in the country, particularly as an important funding source for start up and SMEs, the stakeholders of VC in- 
dustry in Indonesia including the government, the OJK/FSA, the law maker, the Indonesia Venture Capital Association (IVCA), as well as the Shareholders and Management of VC firms (practicioners), are expected to provide strategic steps to revitalize $\mathrm{VC}$ industry in Indonesia. The initiatives need to be prioritized are to improve the VC firms' capital structure and providing appropriate funding sources along with the improvement of VC firms' financial performance.

It is also suggested that further research to be done pertaining to the capital structure of VC firms in Indonesia, for instance the effect of some other internal variables that have not been used in this study and external factors such as the effect of macro-economics. In addition, the determination of the optimal capital structure that maximizes value of the companies in VC industry is an interesting topic to study.

\section{REFERENCES}

Adiyana, I.B.G.N.S. \& Ardiana, P.A. 2014. Pengaruh ukuran perusahaan, risiko bisnis, pertumbuhan aset, profitabilitas dan tingkat likuiditas pada struktur modal. E-Journal Akuntansi Universitas Udayana, 10(1): 14-30.

Al-Najjar, B. \& Taylor, P. 2008. The relationship between capital structure and ownership structure. Managerial Finance, 34(12): 919-933.

Ayed, W.H.B. \& Zouari, S.G. 2014. Capital structure and financing of SMEs: the Tunisian case. International Journal of Economics and Finance, 6(5).

Brigham, E.F. \& Houston, J.F. 2006. Dasar-dasar Manajemen Keuangan. Ali Akbar Yulianto, penerjemah. Jakarta: Salemba Empat.

Boateng, A. 2004. Determinants of capital structure: evidence from international joint ventures in Ghana. International Journal of Social Economics, 31 (1/2): 56-66.

Bahana Pembinaan Usaha Indonesia (BPUI). 2014. Laporan tahunan 2013 PT Bahana Pembinaan Usaha Indonesia (Persero). Jakarta.
Baltagi, B.H. 2005. Econometric Analysis of Panel Data. Third edition. John Wiley \& Sons, Ltd.

Budisulistyawati, A. 2006. Karakteristik modal ventura sebagai lembaga pembiayaan. Yustisia, 68.

Dipo, H. 1993. Sukses Memperoleh Dana Usaha, Dengan Tinjauan Khusus Modal Ventura. Jakarta: Pustaka Utama Grafiti.

Forbes Indonesia. 2015. Smarter E-Economy, 6(11).

Hardiyanto, A.T., Achsani, N.A., Sembel, R. \& Maulana, T.N.A. 2013. Ownership and Determinants Capital Structure of Public Listed Companies In Indonesia: A Panel Data Analysis. International Research Journal of Business Studies, 6(1).

Harris, M. \& Raviv, A. 1991. The theory of capital structure. The Journal of Finance. 46: 297-355.

Hasan, R.B., Mikail, S.A. \& Arifin, M. 2011. Historical development of Islamic venture capital: an appraisal. Journal of Applied Sciences Research, 7(13): 2377-2384.

Hussain, D. 2011. Workshop on Financing for ASEAN MSME in the $21^{\text {st }}$ Century. Malaysian Venture Capital \& Private Equity Association.

Jalil, A. 2005. Islamic Venture Capital: A New Source of Islamic Equity Financing. Conference Paper ESSET, Bangi, Universiti Utara Malaysia.

Jensen, F.E. \& Langemeier, L.N. 1996. Optimal leverage with risk aversion: empirical evidence. Agricultural Finance Review, 56: 85-97.

Joni \& Lina. 2010. Faktor-faktor yang mempengaruhi struktur modal. Jurnal Bisnis dan Akuntansi, 12(2): 81-96.

Krishnan, V.S. \& Moyer, R.C. 1996. Determinants of capital structure: an empirical analysis of firms in industrialized countries. Managerial Finance, 22(2): 39-55.

Long, M.S. \& Malitz, I.B. 1995. Investment Patterns and Financial Leverage in National Bureau of Economic Research: Corporate Capital Structures in the United States. B.M. Friedman (ed). Chicago, The University of Chicago Press.

Lopez-Gracia, J. \& Sogorb-Mira, F. 2008. Testing trade-off and pecking order theories financing SMEs. Small Business Economics, 31: 117-136. 


\section{Jurnal Keuangan dan Perbankan | KEUANGAN}

Vol. 20, No.3, September 2016: 407-416

Mamduh. 2004. Manajemen Keuangan, Edisi 1. Yogyakarta (ID): BPFE.

Manurung, A.H. 2012. Teori Keuangan Perusahaan. Jakarta (ID): PT. Adler Manurung Press.

Mayangsari, S. 2001. Analisis faktor-faktor yang mempengaruhi keputusan pendanaan perusahaan: pengujian pecking order hypothesis. Media Riset Akuntansi, Auditing dan Informasi, 1(3): $1-26$.

Metrick, A. \& Yasuda, A. 2012. Venture Capital and the Finance of Innovation. $2^{\text {nd }}$ edition. John Wiley \& Sons.

Modigliani, F. \& Miller, M. 1966. Cost of capital to electric utility industry. American Economic Review. 56(3): 333-391.

Muliya, L.S. \& Imaniyati, N.S. 2008. Perusahaan modal ventura: dalam perspektif hukum bisnis dan hukum Islam. Bandung: Fakultas Hukum Universitas Islam Negeri Bandung.

Munawar, A., Sanim, B., Manurung, A.H. \& Achsani, N.A. 2010. Struktur Kapital Perusahaan Perkebunan Di Indonesia, Kebijakan, Faktor-Faktor yang Mempengaruhi dan Dampaknya Terhadap Kinerja Perusahaan [Disertasi]. Bogor: Institut Pertanian Bogor.

Myers, S.C. 2001. Capital structure. The Journal of Economic Perspectives, 15(2): 81-102.

Oakey, R. 2007. A commentary on gaps in funding for moderate 'non-stellar' growth small businesses in the United Kingdom. Venture Capital: An International Journal of Entrepreneurial Finance, 9(3): 22335.

Otoritas Jasa Keuangan (OJK). 2013. Statistik 2012 dan Direktori Lembaga Pembiayaan.

Otoritas Jasa Keuangan (OJK). 2014. Statistik 2013 dan Direktori Lembaga Pembiayaan.

Otoritas Jasa Keuangan (OJK). 2015a. Statistik 2014 dan Direktori Lembaga Pembiayaan.

Otoritas Jasa Keuangan (OJK). 2015b. Statistik Triwulan II 2015.

Otoritas Jasa Keuangan (OJK). 2015c. Arah dan Kebijakan Pengaturan Modal Ventura. Materi presentasi Deputi Komisioner Pengawas IKNB II pada Semi- nar Nasional Revitalisasi Modal Ventura di Indonesia. Jakarta.

Panda, S. 2012. Factors affecting capital structure of Indian venture capital-backed growth firms. South Asian Journal of Management, 19(1), 98.

Raharjo, P.G., Hakim, D.B., Manurung, A.H. \& Maulana, T.N.A. 2014. Determinant of capital ratio: a panel data analyisis on state-owned banks in Indonesia. Buletin Ekonomi Moneter dan Perbankan, 16(4).

Saidi. 2004. Faktor-faktor yang mempengaruhi struktur modal pada perusahaan manufaktur go public di BEJ tahun 1997-2002. Jurnal Bisnis dan Ekonomi, 9(1).

Seppa, R. 2008. Capital structure decisions: research in Estonian non-financial companies. Baltic Journal of Management, 3(1): 55-70.

Sitorus, P.M.T., Priyarsono, D.S., Manurung, A.H. \& Maulana, T.N.A. 2014. Analysis of capital structure in corporate telecommunications operators in Indonesia. International Journal of Economics and Management Engineering, 4(3): 64-69.

Stiglitz, J.E. 1969. Are-Examination Of The ModiglianiMiller Theorem: American Economics 28 (1): 167187.

Su, L.D. 2010. Ownership structure, corporate diversification and capital structure. Management Decision, 48(2): 314-339.

Titman, S. \& Wessels, R. 1988. The Determinants of capital structure choice. Journal of Finance. 43(1): 1-19.

Vries, D.A. 2010. The effect of firm characteristics and economics factors on capital structures: a South African study. The Business Review. Cambrige.

Wedig, G., Sloan, F.A., Hassan, M. \& Morrisey, M.A. 1988. Capital structure, ownership, and capital payment policy: the case of hospitals. The Journal of Finance, 43: $21-40$.

Zott, C. 1998. Information, learning and decision-making: applications to venture capital finance and strategic management [dissertation]. Canada: The University of British Columbia. 